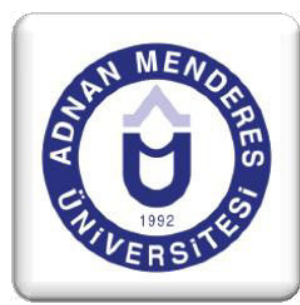

\title{
İktisadi Büyümenin Maliyeti: Cari İşlemler Açı̆̆
}

\section{The Cost of Economic Growth: Current Account Deficit}

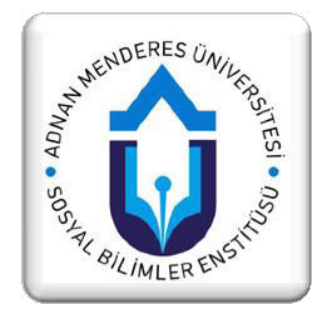

\section{Özet}

Bu çalışmanın amacı iktisadi büyüme ile cari açık arasındaki ilişkiyi bir grup gelişmekte olan ve gelişmiş ülkeler için panel veri analizi kullanılarak analiz etmektir. Gelişmiş ülkeler grubunda Japonya, Kanada, Fransa, Almanya, Italya, Avustralya, Avusturya, Gökhan Birleşik Krallık, Amerika Birleşik Devletleri, Hollanda, Norveç, Ispanya, İsveç, Danimarka, Yunanistan, Portekiz; gelişmekte olan ülkeler grubunda Brezilya, Arjantin, Türkiye, Hindistan, Çin, Güney Afrika, Suudi Arabistan ve Tayland bulunmaktadır. Ekonometrik metod dengeli panel veri analizine dayanmaktadır ve 1974-2011 yılları arasında 38 yıllık bir dönemi kapsamaktadır. Bulgularımıza göre, iktisadi büyüme ile cari açık arasındaki ilişki gelişmiş ülkelerde istatistiksel olarak anlamsızken, gelişmiş ülkeler için bu ilişki anlamlıdır. Bu durumun altında yatan temel sebep, gelişmekte olan ülkelerin ihracatı gelişmişülkelerine göre daha ithalata bağlı olmasından kaynaklanmaktadır.

Anahtar Kelimeler: iktisadi Büyüme, Cari Açık, Panel Veri Analizi, Ihracatın Ithalata Bağımlılı̆ı

JEL Sinıflandırması: O40, F32, C23

\section{Abstract}

The aim of this study is to analyze the relationship between economic growth and current account deficit for some developing and advanced countries by using panel data analysis. Advanced countries group includes Japan, Canada, France, Germany, Italy, Australia, Austria, United Kingdom, United States, Netherlands, Norway, Spain, Sweden, Denmark, Greece and Portugal and developing countries group involves Brazil, Argentina, Turkey, India, China, South Africa, Saudi Arabia and Thailand. The panel is balanced and it covers 38-year period, between 1974-2011, annually. According to our results, whereas the nexus

*Arș. Gör.

Yıldirım Beyazıt

Üniversitesi

Íktisat Bölümü between current account deficit and economic growth is found statistically insignificant for advanced countries and it is found significant for developing countries. The fundamental reason underlying this condition is that export dependency on import is stronger in developing countries than advanced countries.

Keywords: Economic Growth, Current Account Deficit, Panel Data Analysis, Export Dependency on Import

JEL Classification: O40, F32, C23 


\section{Introduction}

The current account balance records transactions emanating from trade in goods and services, from income flowing to residents of one country from another, and from transfers by residents of one country to residents of others (Lipsey and Chrystal, 1999). It is understood clearly with the recent financial crisis that current account balance has significant role in order for providing the macroeconomic stability of an economy. In this sense, the stance of current account position is commonly used as one of the basic indicators for the future behavior of economies. In addition to this, position of current account balance is attributed as an important guide for policy makers for an economy. Because of its extremely important role for stabilization and decision making process, economists have argued the reasons underlying the current account deficit which means that the country imports more goods and services than it exports, while it involves net income transfers such as interest payments and dividends in respect of portfolio investment, direct investment and other investment and transfers from abroad such as foreign aid as well as its impacts on macroeconomic variables. Especially, the relationship between current account deficit and economic growth has been discussing depending upon domestic savings, domestic output growth and real exchange rates in the literature, lately.

As is widely known, economic growth might be achieved through different ways such as increasing domestic demand and raising domestic supply to export. First of all, external sources are needed if domestic demand exceeds domestic supply and savings are not sufficient to finance investment. Increasing domestic demand and, accordingly, increment of external sources in order to provide economic growth is one of the main chronic problems, especially, for developing countries. Secondly, even though high economic growth can be achieved by increasing export, it may lead to dramatic level of current account deficit problem if export is dependent on import and the dependency is so strong. At this point, an important question arises for some countries: "can current account deficit be the cost of economic growth?" With a further explanation, does economic growth lead to dramatic current account deficit level for some countries, for example developing and advanced countries?

The current account deficit would represent economic health of a country when it is meditated with the other economic instruments. If a country has a plausible level current account deficit, it means that the economy is having external debt. If the external debt is used to finance rapid economic growth such as investing in productive sector, the debt can be repaid by higher future output. Besides, the current account deficit can be attractive for capital inflows via interest rate. This type of deficit can be considered as either healthy and growing economy; or, unhealthy and inefficient economy (Lipsey and Chrystal, 1999). 
In this paper, the relation between current account deficit and economic growth will be analyzed for 24 countries; 16 developed and 8 developing countries, separately. Data discrimination enables us to make comparison between these two groups. Besides, panel data approach is applied to comprehend the relation between current account deficit and economic growth for selected group of countries.

The organization of the paper follows as; in the second section literature review is discussed. Third section includes data and methodology. Empirical analysis and results are covered in the fourth section. The last section concludes with some interpretations and suggestions.

\section{Literature Review}

Calderon C., Chong A. and Loayza N. (2000) studied the empirical relationship between current account deficit and a variety set of economic variables for 44 developing countries by drawing panel data set and they found that an increase in domestic output growth generates a larger current account deficit. They also stated that productivity shocks are associated with higher current account deficit and these deficits in developing economies are usually persistent.

Glick R. and Rogoff K. (1993) analyzed the impact of global and country-specific shocks on current account for G7 countries. They achieved a stable correlation between investment and current account. Investment is found very sensitive to both permanent country-specific and global productivity shocks and it responds significantly and positively to the permanent productivity shocks. However, they implied that current account responds negatively and significant to the country-specific shocks whereas it has no response to the global shocks. In their article, it is indicated that, economic growth that is originated from temporary productivity shock would increase current income more than permanent income. Rise in current income wouldn't affect investment and consumption decisions, however, would increase savings of economic agents which leads to current account surplus. By the way, a permanent increase in productivity growth would increase the economic agents' consumption and investment levels more than permanent income level and causes current account deficit to increase.

Clarida R. and Prendergast J. (1999) employed a tractable econometric framework in order to understand if there is a stable underlying structure that connects current account with other macroeconomic variables such as economic growth, world demand and the real exchange rate. They specified that economic growth has an enlarging effect on current account deficit in developed countries.

Obstfeld and Rogoff (1995) stated that the current account deficit is the result of looking-forward dynamic saving-investment decisions of governments and people with regard to their future expectations. 
They identified the 'intertemporal approach' term to explain the future and current saving-investment behavior for current account balance.

Moreno-Brid (1999) employed the basic balance-of-payments constraint model (BPC model) which is developed by A. P. Thirlwall, in order to analyze Mexican economy for the period between 1950-96. He found significant and positive cointegration between Mexico's real export and real output which was the most important factor for Mexico's long-run economic growth. In addition to that, cointegration results showed that the decline in economic growth since 1980s are explained by the increase in the long-term elasticity of imports that made balance of payments constraint more binding.

Gruber and Kamin (2005) studied on 61 countries over the period 1983-2003 by employing panel regression model and found that financial crises restrain domestic demand and boost current account balance. They concluded that strong growth performance and favorable institutional environment attracting foreign investment into the U.S. which significantly reduces the current account balance.

Chinn and Prasad (2000) investigated the medium term determinants of current account for a large sample of industrial and developing countries by using cross-sectional and panel regression techniques. They highlighted that current account balances are positively correlated with government budget balances, financial deepening and initial stocks of net foreign assets in developing countries. However, they indicated that the higher terms of trade volatility leads to the lower current account deficit (the higher current account surplus) among developing countries. However, the degree of openness to international trade is found weakly correlated to larger current account deficit in developing countries. They also concluded that average GDP growth has a systematic relationship with current account balance.

\section{Data and Methodology}

In this paper, countries are divided into two subgroups and analyzed separately to make comparison between advanced and developing countries. Advanced countries group includes Japan, Canada, France, Germany, Italy, Australia, Austria, United Kingdom, United States, Netherlands, Norway, Spain, Sweden, Denmark, Greece and Portugal and developing countries group involves Brazil, Argentina, Turkey, India, China, South Africa, Saudi Arabia and Thailand. The panel is balanced and it covers 38-year period, between 1974-2011, annually. The dependent variable is current account deficit/GDP ratio and the regressor is economic growth rate. The data are obtained from World Bank Online Database. 


\subsection{Panel Unit Root Tests}

Panel data analysis with cross section and time series dimensions has recently come into prominence in econometrics. Panel data analysis essentially concentrates on the unit root properties of variables in an attempt to increase statistical power as the conventional unit root tests are comparatively low power for nonstationary data(Çelik and Özerkek, 2010)The panel unit root tests are classified as first generation and second generation unit root tests. The fundamental difference between first generation and second generation unit root test is cross-sectional dependence. The first generation unit root tests ignore cross-sectional dependence, while second generation tests take into account cross-sectional dependence. In another word, first generation unit root tests are based on cross-sectional independency hypothesis that is rather restrictive and unrealistic in macroeconomic applications (Hurlin and Mignon, 2004).Due to the ignorance of crosssectional dependency, first generation unit root tests lead to size distortions and low power (Strauss and Yiğit, 2003). Second generation unit root tests try to surmount this deficiency by regarding dependency between the cross-sections (Werkmann, 2011).

Levin, Lin and Chu test (LLC hereafter.) allows heterogeneity of individual deterministic effects and heterogeneous serial correlation structure of the error terms assuming that homogenous first order autoregressive parameters (Barbieri, 2005). There are two noteworthy outcomes of the LLC test. First of all, it depends on the assumption that cross sections are independent of each other. Secondly, autoregressive parameters among cross sections are considered to be identical in the panel.Im, Pesaran and Shin (2003) (IPS henceforth.) expanded the LLC test in order to overcome limitations of LLC test. IPS is an individual unit root test which means that autoregressive parameters differ among cross-sections, i.e. by allowing heterogeneity. On the other hand, second generation unit root tests assume that cross sections are dependent of each other.

In this analysis, LLC and IPS tests are applied as first generation panel unit root tests Moon and Perron unit root test is applied as a second generation unit root test because when $\mathrm{N} / \mathrm{T} \rightarrow 0$, the statistics have a limiting standard normal distribution under the null hypothesis in Moon and Perron unit root test. The results of panel unit root tests for advanced and developing countries are presented in Table 1.

Table 1: Panel Unit Root Tests

\begin{tabular}{|c|c|c|c|c|c|}
\hline \multirow{3}{*}{ Group } & \multirow{2}{*}{$\begin{array}{c}\text { Varia } \\
\text { ble }\end{array}$} & \multirow{2}{*}{ Case } & \multicolumn{2}{|c|}{$1^{\text {st Generation }}$} & \multicolumn{2}{c|}{$2^{\text {nd }}$ Generation } \\
\cline { 3 - 6 } & & Com & Indivi & \multicolumn{2}{|c|}{ Moon and Perron } \\
\cline { 3 - 6 } & & LLC & IPS & tstar_a & tstar_b \\
\hline
\end{tabular}




\begin{tabular}{|c|c|c|c|c|c|c|}
\hline \multirow{4}{*}{$\begin{array}{l}\text { advance } \\
\text { d }\end{array}$} & \multirow{2}{*}{ cad } & constant & $\begin{array}{l}-1.372 \\
(0.0851)\end{array}$ & $\begin{array}{c}- \\
1.558 \\
(0.05 \\
96)\end{array}$ & $11.088^{-}$ & $-5.252 *$ \\
\hline & & d constantandtren & $\begin{array}{c}- \\
2.071 * \\
(0.019 \\
1)\end{array}$ & $\begin{array}{c}- \\
3.479 * \\
(0.00 \\
03)\end{array}$ & $-2.934 *$ & $-2.295^{*}$ \\
\hline & \multirow{2}{*}{$\begin{array}{l}\text { grow } \\
\text { th }\end{array}$} & constant & $\begin{array}{c}{ }^{-} \\
13.867 * \\
\quad(0.000 \\
\quad)\end{array}$ & $\begin{array}{c}-\overline{-} \\
13.403 * \\
(0.00 \\
0)\end{array}$ & $31.576^{-}$ & $10.141^{-}$ \\
\hline & & d constantandtren & $\begin{array}{c}- \\
12.070^{*} \\
(0.000 \\
)\end{array}$ & $\begin{array}{c}- \\
11.808 * \\
(0.00 \\
0)\end{array}$ & $-22.31 *$ & $15.405^{-}$ \\
\hline \multirow{4}{*}{$\begin{array}{l}\text { developi } \\
\mathrm{ng}\end{array}$} & \multirow{2}{*}{ cad } & constant & $\begin{array}{l}-2.83 * \\
(0.002 \\
3)\end{array}$ & $\begin{array}{c}- \\
2.847^{*} \\
(0.00 \\
22)\end{array}$ & $-9.196 *$ & $-3.448 *$ \\
\hline & & d constantandtren & $\begin{array}{l}- \\
3.384 * \\
(0.000 \\
4)\end{array}$ & $\begin{array}{c}- \\
2.269^{*} \\
0.011 \\
6\end{array}$ & $-3.25^{*}$ & $-2.599 *$ \\
\hline & \multirow{2}{*}{$\begin{array}{l}\text { grow } \\
\text { th }\end{array}$} & constant & $\begin{array}{c}- \\
9.279 * \\
(0.000 \\
\quad\end{array}$ & $\begin{array}{c}- \\
9.689^{*} \\
(0.00 \\
0)\end{array}$ & $-15.24^{*}$ & $10.278 *$ \\
\hline & & d constantandtren & $\begin{array}{c}- \\
10.246^{*} \\
(0.000 \\
)\end{array}$ & $\begin{array}{c}- \\
9.838^{*} \\
(0.00 \\
0)\end{array}$ & $26.893 *$ & $-8.966^{*}$ \\
\hline
\end{tabular}

Automatic Schwarz Information Criteria are chosen to specify the length for LLC and IPS tests. Maximum laglength is set to 1 for all tests. The values in brackets are the p-values for LLC and IPS tests. However, Moon and Perron test has normal distribution and critical value is -1.645. (*) denotes significance at $5 \%$ level and rejection of null hypothesis that existence of unit root. 
According to results, we reject the null hypothesis that existence of unit root in the variables for 6 out of 8 for advanced countries for the $1^{\text {st }}$ generation unit root tests. For developing countries, 8 out of 8 are found stationary for the $1^{\text {st }}$ generation unit root tests. Similarly, according to Moon and Perron test, we reject the null hypothesis that presence of unit root in all cases for each variable for both country groups. All these results assure that the series are stationary.

\subsection{Random Effects and Fixed Effects Methods}

Random and fixed effects methods are useful approach in order to understand the relation between the variables in panel data analysis. In this sense, consider a model with a single explanatory variable for a balanced panel data set : for each $\mathrm{i}$

$$
\mathrm{Y}_{\mathrm{it}}=\beta_{1} \mathrm{x}_{\mathrm{it}}+\mathrm{a}_{\mathrm{i}}+\mathrm{u}_{\mathrm{it}}
$$

since $\mathrm{t}=1,2,3, \ldots, \mathrm{T}$ and $\mathrm{a}_{\mathrm{i}}=$ unobserved effect

When $a_{i}$ is correlated with one or more explanatory variables, it can be eliminated because of this dependence between variables and unobserved effect. A pooled estimator that is based on the time-demeaned variables is called the fixed effects estimator or within estimator. If $a_{i}$ is uncorrelated with each explanatory variable, using the random effects method is better (Wooldridge, 2002).Both random effects and fixed effects have own advantages and disadvantages. A fixed effects estimator could not estimate a coefficient on any time-variant regressor, like schooling and sex, because individual intercepts are free to take any value. However, in arandom effects model, individual effects are part of the error term, hence, it must be uncorrelated with regressor. Moreover, because individual effects in random effects are as part of error term, it encounters with the possibility of bias because of a correlation between it and regressor (Dewan and Hussein, 2001).

Hausman (1978) suggests a test which is known as Hausman Test to distinguish between the random effects and fixed effects. The test which is named as Hausman Test is related to compare the difference between the two estimators of the coefficient vectors that random effects estimator is consistent and efficient under the null hypothesis and inconsistent under alternative hypothesis while fixed effects estimator is consistent under the null and alternative hypothesis (Dewan and Hussein, 2001). In addition to Hausman test, Baltagi suggests to use fixed effect model if the analysis focuses on a specific set of $\mathrm{N}$ firms, such as IBN and Westinghouse. Besides, he also advices to use fixed effects model if the sample is composed of a 
specific country groups, such as a set of N OECD countries or N American states (Baltagi, 2005).Because our sample comprises two different country groups, advanced and developing countries, separately, fixed effects model will be employed in this study with respect to view of Baltagi.

\section{Empirical Results}

Table 2: Fixed Effects Results

\begin{tabular}{|c|c|c|c|}
\hline \multirow{2}{*}{ Advanced } & Growth & $\mathrm{R}^{2}$ & $\begin{array}{c}\text { Number of } \\
\text { Observations }\end{array}$ \\
\hline & $\begin{array}{l}0.0036 \\
(0.973)\end{array}$ & 0.000 & 608 \\
\hline Developing & $\begin{array}{l}0.096^{*} \\
(0.045)\end{array}$ & 0.015 & 295 \\
\hline
\end{tabular}

Notes:

1)* denotes statistical significance at the $5 \%$ level.

2) The parenthesis indicates t statistics.

Our results highlight that there is statistically insignificant relation between current account deficit and economic growth for advanced countries. Meaning of this evidence is that economic growth and current account deficit do not move together for advanced economies. Export-import independency can be accounted as the major reason for this economic growth-current account deficit independency. Contrary to advanced economies, the relationship between current account deficit and economic growth is found statistically significant and positive at the $\% 5$ significance level with the coefficient of 0,096 in developing countries. Export dependency on import is the fundamental cause of this relation because import is the first step to make production and export goods and services in these countries. Lack of information, short of resources, deficient technology, unqualified education, unskilled labors are some of the reasons lying behind 
export-import dependency. In another words, the more exports, the more import which causes more current account balance deterioration.

\section{Concluding Remarks}

This paper mainly tried to understand if there is a relationship between economic growth and current account deficit in developing and advanced countries, separately. The pervasive perception about the relationship between current account balance and economic growth is to be negative, especially for the developing economies. Our results confirm that economic growth and current account balance are correlated negatively in developing countries. On the other hand, for advanced economies, the relationship is found insignificant. The structure of export and import can be considered as the most influential factor causing this distinction between developing and advanced economies because trade balance is the most important section of current account balance. Developing economies' ability to produce usually depends on their import. With a further explanation, an increased in economic growth means an increase in import at the same time. Given the exports level, an increment in importrate to provide economic growth via export results in trade deficit and current account deficit as well. It should be comprehended that in order to achieve rapid economic growth without creating current account deficit, the dependence of export on import should be reduced in developing countries. These types of countries substantially import intermediate goods in order to make final good production and export. So, it is crucial to develop sectors which produce semi-finished goods to avoid export-import dependency.

Additionally, high ratio of FDI to GDP is desired to finance current account deficit and maintain economic growth in developing economies, which is indeed another reason of positive current account deficit-economic growth relation in those countries. FDI is a vital source for economic growth in emerging economies because it is usually used to finance investment. On the other hand, attracting FDI has become one of the major economic issues in developing economies because of increasing fragility of economies and profit repatriation. Profit repatriation leads to deterioration of current account balance and the fragility make this connection not only an economic both also a political issue, which should be considered seriously by economists and politicians. 


\section{REFERENCES}

Baltagi, B. H., 2005. Econometric Analysis of Panel Data.England: John Wiley\&Sons Ltd.

Barbieri, L.,2005. Panel UnitRootTests: A Review.Piacenza: UniversitàCattolica del SacroCuore.

Çelik S. and Özerkek Y., 2010.The Link Between Governent Spending, Consumer Confidence and Consumption Expenditures in Emerging Market Countries.Panoeconomicus, 4, pp. 471-485.

Dewan, E and S. Hussein., 2001. Determinants of EconomicGrowth.WorkingPaper, Reserve Bank of Fiji.

Hausman. J. A., 1978.SpecificationTests in Econometrics.Econometrica,46(6).pp.1251-1271.

Hurlin, C.,Mignon, V., 2004. Second generation panel unit root tests. University of Paris X, Mimeo.

Lipsey R. G. and Chrystal K. A., 1999. Principles of Economics. Oxford: Oxford University. Press

Strauss, J. andYigit, T., 2003 .Shortfalls of Panel UnitRootTesting.EconomicsLetters. 81, pp. 309-313.

Werkmann, V., 2011. Performance of UnitRootTests in UnbalancedPanels - ExperimentalEvidence. [Online] Available at: http://www.wiwi.unifrankfurt.de/ei/fileadmin/hassler/werkmann1.pdf. [Accessed in 1 December 2012]

Wooldridge, M. J., 2002. Introductory Econometrics: A Modern Approach. South-Western CollegePub. 


\section{Statistical Appendix:}

Table 3: Descriptive Statistics for Developing Countries

\begin{tabular}{|c|c|c|c|c|c|c|c|c|c|c|}
\hline $\begin{array}{l}\text { Countri } \\
\text { es }\end{array}$ & $\begin{array}{l}\text { Variabl } \\
\text { es }\end{array}$ & $\begin{array}{l}\mathrm{Me} \\
\text { an }\end{array}$ & $\begin{array}{l}\text { Medi } \\
\text { an }\end{array}$ & $\begin{array}{l}\mathrm{Ma} \\
\mathrm{x} .\end{array}$ & Min & $\begin{array}{l}\text { Std. } \\
\text { Dev. }\end{array}$ & $\begin{array}{l}\text { Skewne } \\
\text { ss }\end{array}$ & $\begin{array}{l}\text { Kurto } \\
\text { sis }\end{array}$ & $\begin{array}{r}\text { Jarq } \\
\text { ue-Bera }\end{array}$ & $\begin{array}{l}\mathrm{Ob} \\
\mathrm{s} .\end{array}$ \\
\hline \multirow{2}{*}{ Brazil } & cad & 1.943 & 2.053 & $8^{1.76}$ & 5.793 & $\begin{array}{l}2.25 \\
7\end{array}$ & 0.025 & 1.800 & $\begin{array}{l}2.28 \\
1\end{array}$ & 38 \\
\hline & growth & $\begin{array}{r}3.3 \\
93 \\
\end{array}$ & $\begin{array}{l}3.48 \\
7\end{array}$ & $\begin{array}{l}9.79 \\
0\end{array}$ & 4.393 & $\begin{array}{l}3.52 \\
3\end{array}$ & -0.327 & 2.779 & $\begin{array}{l}0.75 \\
3\end{array}$ & 38 \\
\hline \multirow{2}{*}{$\begin{array}{l}\text { Argenti } \\
\text { na }\end{array}$} & cad & $\begin{array}{r}- \\
0.574\end{array}$ & 1.161 & $\begin{array}{l}8.59 \\
1\end{array}$ & $6.20 \overline{3}$ & $\begin{array}{l}3.35 \\
2\end{array}$ & 0.555 & 2.992 & $\begin{array}{l}1.95 \\
1\end{array}$ & 38 \\
\hline & growth & $\begin{array}{l}2.8 \\
37\end{array}$ & $\begin{array}{l}4.01 \\
3\end{array}$ & $\begin{array}{c}12.6 \\
70\end{array}$ & 10.894 & $\begin{array}{l}6.22 \\
4\end{array}$ & -0.391 & 2.020 & $\begin{array}{l}2.49 \\
0\end{array}$ & 38 \\
\hline \multirow{2}{*}{ Turkey } & cad & 2.397 & 1.938 & $\begin{array}{l}2.01 \\
3\end{array}$ & $9.99 \overline{1}$ & $\begin{array}{l}2.56 \\
6\end{array}$ & -0.556 & 3.541 & $\begin{array}{l}2.42 \\
1\end{array}$ & 38 \\
\hline & growth & $\begin{array}{l}4.3 \\
06\end{array}$ & $\begin{array}{l}5.15 \\
0\end{array}$ & $\begin{array}{c}10.4 \\
61\end{array}$ & 5.697 & $\begin{array}{l}4.38 \\
2\end{array}$ & -0.793 & 2.678 & $\begin{array}{l}4.14 \\
4\end{array}$ & 38 \\
\hline \multirow{2}{*}{ India } & cad & $0.90 \overline{2}$ & 1.025 & $\begin{array}{l}1.71 \\
4\end{array}$ & $\begin{array}{r}- \\
3.074\end{array}$ & $\begin{array}{l}1.20 \\
1\end{array}$ & 0.570 & 2.676 & $\begin{array}{l}2.22 \\
0\end{array}$ & 38 \\
\hline & growth & $\begin{array}{l}5.7 \\
75\end{array}$ & $\begin{array}{l}5.97 \\
7\end{array}$ & $\begin{array}{l}9.80 \\
1\end{array}$ & $5.238^{-}$ & $\begin{array}{l}2.97 \\
7\end{array}$ & -1.334 & 6.123 & $\begin{array}{l}26.7 \\
00\end{array}$ & 38 \\
\hline \multirow{2}{*}{ China } & cad & $03^{2.5}$ & $\begin{array}{l}2.19 \\
3 \\
\end{array}$ & $\begin{array}{l}10.1 \\
31\end{array}$ & 3.723 & $\begin{array}{l}3.30 \\
3\end{array}$ & 0.413 & 3.057 & $\begin{array}{l}0.85 \\
7 \\
\end{array}$ & 30 \\
\hline & growth & $\begin{array}{c}9.3 \\
71\end{array}$ & $\begin{array}{l}9.25 \\
0\end{array}$ & $\begin{array}{l}15.2 \\
00\end{array}$ & $1.600^{-}$ & $\begin{array}{l}3.42 \\
1\end{array}$ & -0.933 & 4.553 & $\begin{array}{l}9.33 \\
1\end{array}$ & 38 \\
\hline \multirow{2}{*}{$\begin{array}{l}\text { South } \\
\text { Africa }\end{array}$} & cad & 0.997 & 0.777 & $\begin{array}{l}5.30 \\
1\end{array}$ & 7.333 & $\begin{array}{l}3.36 \\
5\end{array}$ & -0.093 & 2.174 & $\begin{array}{l}1.13 \\
4\end{array}$ & 38 \\
\hline & growth & $\begin{array}{c}2.5 \\
17\end{array}$ & $\begin{array}{l}2.91 \\
9\end{array}$ & $\begin{array}{l}6.62 \\
1\end{array}$ & 2.137 & $\begin{array}{l}2.37 \\
8\end{array}$ & -0.355 & 2.196 & $2^{1.82}$ & 38 \\
\hline \multirow{2}{*}{$\begin{array}{l}\text { SaudiA } \\
\text { rabia }\end{array}$} & cad & $\begin{array}{r}6.1 \\
46 \\
\end{array}$ & $\begin{array}{l}5.03 \\
3 \\
\end{array}$ & $\begin{array}{c}51.1 \\
77 \\
\end{array}$ & $\begin{array}{c}- \\
20.946 \\
\end{array}$ & $\begin{array}{l}17.0 \\
80\end{array}$ & 0.476 & 2.470 & $\begin{array}{l}1.88 \\
0\end{array}$ & 38 \\
\hline & growth & $\begin{array}{c}3.4 \\
51\end{array}$ & $\begin{array}{l}3.80 \\
6\end{array}$ & $\begin{array}{l}27.4 \\
92\end{array}$ & 11.098 & $\begin{array}{l}6.31 \\
0\end{array}$ & 1.019 & 7.340 & $\begin{array}{l}36.3 \\
98\end{array}$ & 38 \\
\hline \multirow{2}{*}{$\begin{array}{l}\text { Thailan } \\
\text { d }\end{array}$} & cad & $1.428^{-}$ & $\begin{array}{r}- \\
3.099\end{array}$ & $\begin{array}{l}12.7 \\
32\end{array}$ & 8.531 & $\begin{array}{l}5.65 \\
4\end{array}$ & 0.754 & 2.600 & $\begin{array}{l}3.84 \\
9\end{array}$ & 38 \\
\hline & growth & $\begin{array}{l}5.7 \\
48\end{array}$ & $\begin{array}{l}5.55 \\
9\end{array}$ & $\begin{array}{c}13.2 \\
88\end{array}$ & $\begin{array}{c}- \\
10.510\end{array}$ & $\begin{array}{l}4.30 \\
8\end{array}$ & -1.441 & 6.881 & $\begin{array}{l}37.0 \\
04\end{array}$ & 38 \\
\hline
\end{tabular}


Table 4: Descriptive Statistics for Developed Countries

\begin{tabular}{|c|c|c|c|c|c|c|c|c|c|c|}
\hline $\begin{array}{l}\text { Countrie } \\
\mathrm{S} \\
\end{array}$ & $\begin{array}{l}\text { Vari } \\
\text { ables }\end{array}$ & $\begin{array}{l}\mathrm{Me} \\
\text { an }\end{array}$ & $\begin{array}{l}\text { Medi } \\
\text { an }\end{array}$ & Max. & Min. & $\begin{array}{l}\text { Std. } \\
\text { Dev. }\end{array}$ & $\begin{array}{l}\text { Skewne } \\
\text { ss }\end{array}$ & $\begin{array}{l}\text { Kurto } \\
\text { sis } \\
\end{array}$ & $\begin{array}{l}\text { Jarqu } \\
\text { e-Bera }\end{array}$ & $\begin{array}{l}\mathrm{O} \\
\text { bs. } \\
\end{array}$ \\
\hline \multirow{2}{*}{ Japan } & cad & $\begin{array}{l}2.2 \\
52 \\
\end{array}$ & 2.557 & 4.859 & -0.989 & 1.361 & -0.575 & 2.897 & 2.112 & $8^{3}$ \\
\hline & $\begin{array}{l}\text { grow } \\
\text { th }\end{array}$ & $\begin{array}{r}2.3 \\
33 \\
\end{array}$ & 2.485 & 7.147 & -5.527 & 2.566 & -0.630 & 3.778 & 3.471 & $8^{3}$ \\
\hline \multirow{2}{*}{ Canada } & cad & $\begin{array}{r}- \\
1.511 \\
\end{array}$ & $\begin{array}{r}- \\
2.286\end{array}$ & 2.707 & -4.802 & 2.240 & 0.437 & 1.779 & 3.568 & $8^{3}$ \\
\hline & $\begin{array}{l}\text { grow } \\
\text { th }\end{array}$ & $\begin{array}{r}2.7 \\
18 \\
\end{array}$ & 2.874 & 5.814 & -2.859 & 2.069 & -1.106 & 4.242 & $\begin{array}{l}10.19 \\
0\end{array}$ & $8^{3}$ \\
\hline \multirow{2}{*}{ France } & cad & $\begin{array}{r}0.0 \\
96 \\
\end{array}$ & $\begin{array}{r}- \\
0.053 \\
\end{array}$ & 3.149 & -2.165 & 1.283 & 0.378 & 2.788 & 0.978 & $8^{3}$ \\
\hline & $\begin{array}{l}\text { grow } \\
\text { th }\end{array}$ & $\begin{array}{r}2.0 \\
27^{2} \\
\end{array}$ & 2.115 & 4.691 & -3.147 & 1.606 & -0.809 & 4.518 & 7.798 & $8^{3}$ \\
\hline \multirow{2}{*}{$\begin{array}{l}\text { German } \\
\mathrm{y}\end{array}$} & cad & $52^{1.7}$ & 1.020 & 7.485 & -1.722 & 2.758 & 0.494 & 1.962 & 3.248 & $8^{3}$ \\
\hline & $\begin{array}{l}\text { grow } \\
\text { th }\end{array}$ & $\begin{array}{l}1.9 \\
05^{2}\end{array}$ & 1.866 & 5.255 & -5.127 & 1.986 & -1.001 & 5.449 & $\begin{array}{l}15.84 \\
8 \\
\end{array}$ & $8^{3}$ \\
\hline \multirow{2}{*}{ Italy } & cad & $\begin{array}{r}- \\
0.711 \\
\end{array}$ & $\begin{array}{r}- \\
0.887 \\
\end{array}$ & 3.159 & -4.304 & 1.805 & 0.274 & 2.412 & 1.024 & $8^{3}$ \\
\hline & $\begin{array}{l}\text { grow } \\
\text { th }\end{array}$ & $\begin{array}{l}1.8 \\
50 \\
\end{array}$ & 1.834 & 7.125 & -5.494 & 2.211 & -0.561 & 5.361 & $\begin{array}{l}10.81 \\
7 \\
\end{array}$ & $8^{3}$ \\
\hline \multirow{2}{*}{$\begin{array}{l}\text { Australi } \\
\text { a }\end{array}$} & cad & 4.162 & $\begin{array}{r}- \\
4.266 \\
\end{array}$ & $\begin{array}{r}- \\
1.078 \\
\end{array}$ & -6.771 & 1.356 & 0.219 & 2.429 & 0.819 & $8^{3}$ \\
\hline & $\begin{array}{l}\text { grow } \\
\text { th }\end{array}$ & $\begin{array}{l}3.1 \\
71\end{array}$ & 3.569 & 5.872 & -2.320 & 1.607 & -1.338 & 5.220 & $\begin{array}{l}19.13 \\
6\end{array}$ & $8^{3}$ \\
\hline \multirow{2}{*}{ Austria } & cad & $\begin{array}{r}- \\
0.317 \\
\end{array}$ & 0.247 & 4.860 & -5.476 & 2.392 & -0.051 & 2.573 & 0.306 & $8^{3}$ \\
\hline & $\begin{array}{l}\text { grow } \\
\text { th }\end{array}$ & $2^{2.3}$ & 2.429 & 5.456 & -3.810 & 1.769 & -1.050 & 5.124 & $\begin{array}{l}14.12 \\
7\end{array}$ & $8^{3}$ \\
\hline \multirow{2}{*}{$\begin{array}{l}\text { United } \\
\text { Kingdom }\end{array}$} & cad & $\begin{array}{r}- \\
1.342^{-} \\
\end{array}$ & $\begin{array}{r}- \\
1.660 \\
\end{array}$ & 2.743 & -5.016 & 1.708 & 0.179 & 2.783 & 0.277 & $8^{3}$ \\
\hline & $\begin{array}{l}\text { grow } \\
\text { th }\end{array}$ & $\begin{array}{l}2.1 \\
48 \\
\end{array}$ & 2.673 & 6.207 & -4.373 & 2.242 & -0.949 & 3.554 & 6.194 & $8^{3}$ \\
\hline \multirow{2}{*}{$\begin{array}{l}\text { United } \\
\text { States }\end{array}$} & cad & $\begin{array}{r}- \\
2.288^{-} \\
\end{array}$ & $2.112^{-}$ & 1.101 & -6.013 & 1.899 & -0.244 & 2.117 & 1.612 & $8^{3}$ \\
\hline & $\begin{array}{l}\text { grow } \\
\text { th }\end{array}$ & $\begin{array}{l}2.6 \\
89^{2}\end{array}$ & 3.112 & 7.195 & -3.527 & 2.198 & -0.771 & 3.598 & 4.326 & $8^{3}$ \\
\hline $\begin{array}{l}\text { Netherla } \\
\text { nd }\end{array}$ & cad & $9^{3.8}$ & 3.553 & 9.306 & -0.622 & 2.362 & 0.402 & 2.914 & 1.033 & $8^{3}$ \\
\hline
\end{tabular}




\begin{tabular}{|c|c|c|c|c|c|c|c|c|c|c|}
\hline & $\begin{array}{l}\text { grow } \\
\text { th }\end{array}$ & $\begin{array}{r}2.3 \\
14^{-} \\
\end{array}$ & 2.385 & 4.788 & -3.537 & 1.769 & -1.136 & 4.662 & $\begin{array}{l}12.54 \\
5\end{array}$ & $8^{3}$ \\
\hline \multirow{2}{*}{ Norway } & cad & $\begin{array}{l}4.5 \\
07\end{array}$ & 3.499 & $\begin{array}{l}17.45 \\
7\end{array}$ & $\begin{array}{c}- \\
12.304\end{array}$ & 8.146 & -0.138 & 2.158 & 1.244 & $8^{3}$ \\
\hline & $\begin{array}{l}\text { grow } \\
\text { th }\end{array}$ & $\begin{array}{l}2.9 \\
10^{2}\end{array}$ & 2.946 & 5.894 & -1.667 & 1.843 & -0.358 & 2.486 & 1.229 & $8^{3}$ \\
\hline \multirow{2}{*}{ Spain } & cad & $\begin{array}{r}- \\
2.783 \\
\end{array}$ & $\begin{array}{r}- \\
2.718^{-} \\
\end{array}$ & 1.604 & $\begin{array}{c}- \\
10.028 \\
\end{array}$ & 2.829 & -0.837 & 3.656 & 5.116 & $8^{3}$ \\
\hline & $\begin{array}{l}\text { grow } \\
\text { th }\end{array}$ & $\begin{array}{l}2.5 \\
08\end{array}$ & 2.734 & 5.619 & -3.741 & 1.982 & -0.800 & 3.966 & 5.532 & $8^{3}$ \\
\hline \multirow{2}{*}{ Sweden } & cad & $\begin{array}{l}1.8 \\
07^{1.8} \\
\end{array}$ & 0.182 & 9.363 & -3.306 & 4.006 & 0.469 & 1.828 & 3.566 & $8^{3}$ \\
\hline & $\begin{array}{l}\text { grow } \\
\text { th }\end{array}$ & $\begin{array}{l}2.1 \\
38 \\
\end{array}$ & 2.610 & 6.153 & -5.028 & 2.256 & -1.057 & 4.213 & 9.412 & $8^{3}$ \\
\hline \multirow{2}{*}{$\begin{array}{l}\text { Denmar } \\
\mathrm{k}\end{array}$} & cad & $\begin{array}{l}0.1 \\
11 \\
\end{array}$ & 1.014 & 6.668 & -5.199 & 3.157 & -0.005 & 1.904 & 1.903 & $8^{3}$ \\
\hline & $\begin{array}{l}\text { grow } \\
\text { th }\end{array}$ & $\begin{array}{l}1.7 \\
30^{1.7} \\
\end{array}$ & 1.977 & 6.094 & -5.834 & 2.231 & -0.757 & 4.872 & 9.178 & $8^{3}$ \\
\hline \multirow{2}{*}{ Greece } & cad & $\begin{array}{r}- \\
5.186 \\
\end{array}$ & $\begin{array}{r}- \\
3.887 \\
\end{array}$ & 0.131 & $\begin{array}{c}- \\
15.039 \\
\end{array}$ & 3.645 & -1.123 & 3.669 & 8.700 & $8^{3}$ \\
\hline & $\begin{array}{l}\text { grow } \\
\text { th }\end{array}$ & $\begin{array}{l}1.7 \\
51 \\
\end{array}$ & 2.434 & 7.247 & -6.907 & 3.371 & -0.741 & 3.218 & 3.550 & $8^{3}$ \\
\hline \multirow{2}{*}{ Portugal } & cad & $\begin{array}{r}- \\
5.208^{-}\end{array}$ & $\begin{array}{r}- \\
5.128 \\
\end{array}$ & 3.049 & $\begin{array}{c}- \\
14.852 \\
\end{array}$ & 4.608 & -0.127 & 1.927 & 1.926 & $8^{3}$ \\
\hline & $\begin{array}{l}\text { grow } \\
\text { th }\end{array}$ & $\begin{array}{r}2.3 \\
68 \\
\end{array}$ & 2.250 & 7.489 & -4.348 & 2.851 & -0.299 & 2.526 & 0.924 & $8^{3}$ \\
\hline
\end{tabular}

